\title{
MORPHOLOGY AND PRODUCTIVITY OF “JUREMINHA" GENOTYPES (Desmanthus spp.) UNDER DIFFERENT CUTTING INTENSITIES ${ }^{1}$
}

\author{
THIAGO BEZERRA CALADO ${ }^{2 *}$, MÁRCIO VIEIRA DA CUNHA ${ }^{2}$, VICENTE IMBROISI TEIXEIRA ${ }^{3}$, MÉRCIA \\ VIRGINIA FERREIRA DOS SANTOS ${ }^{2}$, HACTUS SOUTO CAVALCANTI ${ }^{3}$, CAROLINA CÂMARA LIRA ${ }^{2}$
}

\begin{abstract}
The aim of the study was to evaluate the morphological and productive characteristics of five genotypes of Desmanthus spp. submitted to two cutting intensities $(20$ and $40 \mathrm{~cm})$, in the semi-arid region of Pernambuco. Of the genotypes studied, three were derived from ecotypes collected in municipalities of Pernambuco $(7 \mathrm{G}, 31 \mathrm{D}$ and $50 \mathrm{~J})$ and two were from the state of Sergipe, coming from Australia (10AU and 13AU). Four cuttings were made with a frequency of 60 days. The treatments were randomized in blocks, with split plots and three replications. The variables studied were plant height, stem diameter, canopy diameter, the number of leaves per branch, LAI, leaf yield, stem yield, pod yield and forage yield, and leaf stem ${ }^{-1}$ ratio and $^{-1}$ pod stem $^{-1}$ ratio. Genotypes $7 \mathrm{G}$ and $31 \mathrm{D}$ had higher forage yield and a larger number of leaves per branch. Forage yield was higher in the intensity of $20 \mathrm{~cm}$. The cuttings reduced the total yield, stem yield, pods yield and forage yield, of the different genotypes studied. For leaf stem ${ }^{-1}$ ratio, the genotype 13AU was higher than genotypes $7 \mathrm{G}$ and $50 \mathrm{~J}$ in the cutting intensity of $40 \mathrm{~cm}$. Genotype $10 \mathrm{AU}$ had the highest pod stem ${ }^{-1}$ ratios in the three cuttings. The differences shown between genotypes of Desmanthus spp., especially $7 \mathrm{G}$ and $31 \mathrm{D}$, in the intensity of $20 \mathrm{~cm}$, indicate the possibility of selecting promising materials for cultivation in the semi-arid region of Pernambuco, with desirable morphological and productive characteristics to the forage plants.
\end{abstract}

Keywords: Cutting height. Native legumes. Forage yield. Semi-arid.

\section{MORFOLOGIA E PRODUTIVIDADE DE GENÓTIPOS DE JUREMINHA (Desmanthus spp.) SOB DIFERENTES INTENSIDADES DE CORTE}

RESUMO - O objetivo do trabalho foi avaliar características morfológicas e produtivas de cinco genótipos de Desmanthus spp., submetidos a duas intensidades de corte $(20$ e $40 \mathrm{~cm})$ no Semiárido de Pernambuco. Dos genótipos estudados, três foram oriundos de ecótipos coletados em municípios de Pernambuco (7G, 31D e 50J) e dois advindos do estado de Sergipe, oriundos da Austrália (10AU e 13AU). Foram realizados quatro cortes, com frequência de 60 dias. Os tratamentos foram casualisados em blocos, com parcelas subdivididas e três repetições. As variáveis estudadas foram altura da planta, diâmetro do caule, diâmetro da copa, número de folhas/ramo, IAF, produção de folhas, de caule, de vagem e de forragem, relação folha/caule e vagem/caule. Os genótipos $7 \mathrm{G}$ e $31 \mathrm{D}$ apresentaram maior produção de forragem e maior quantidade de folhas por ramo. A produção de forragem foi maior na intensidade de $20 \mathrm{~cm}$. Os cortes influenciaram a produção de massa seca total, de caule, de vagem e de forragem dos diferentes genótipos estudados. Para a relação folha/caule o genótipo $13 \mathrm{AU}$ foi superior aos $7 \mathrm{G}$ e $50 \mathrm{~J}$ na intensidade de corte $40 \mathrm{~cm}$. O genótipo $10 \mathrm{AU}$ obteve as maiores relações vagem/caule nos três cortes. As diferenças apresentadas entre os genótipos de Desmanthus spp., com destaque para o $7 \mathrm{G}$ e $31 \mathrm{D}$, na intensidade de $20 \mathrm{~cm}$, indicam a possibilidade selecionar materiais promissores para o cultivo no Semiárido de Pernambuco, com características morfológicas e produtivas desejáveis às plantas forrageiras.

Palavras-chave: Altura de corte. Leguminosa nativa. Produção de forragem. Semiárido.

\footnotetext{
*Corresponding author

${ }^{1}$ Received for publication in $06 / 23 / 2015$; accepted in 04/02/2016.

Paper extracted from the master dissertation of the first author.

${ }^{2}$ Departament of Animal Science, Universidade Federal Rural de Pernambuco, Recife, PE, Brazil; thiagobcalado@gmail.com, marcio.cunha@ufrpe.br, mercia.vfsantos@ufrpe.br, camaralira@gmail.com.

${ }^{3}$ Academic Unit Serra Talhada, Universidade Federal Rural de Pernambuco, Serra Talhada, PE, Brazil; vicente_ufrpe@hotmail.com, hactus_souto@hotmail.com.
} 


\section{INTRODUCTION}

The native plants of Caatinga represent an important forage resource for ruminant yield in the northeast of Brazil. Traditionally, they are used for grazing in the environment where they occur naturally, especially in the rainy season. One of these plants is a legume known as "jureminha", or bundleflower (Desmanthus spp.).

"Jureminha" species occur throughout America. In Brazil, especially in its northeastern region, there is a predominant occurrence of Desmanthus pernambucanus (L.) Thell. (PENGELLY; LIU, 2001), which is a member of the species complex of Desmanthus virgatus L. Willd. (LUCKOW, 1993). These species are shrub-like, drought resistant (BREWBAKER, 1987) and nitrogen- fixing (FREITAS et al., 2011).

The cultivation of this plant in northeastern Brazil is practically nonexistent, but in some countries such as Australia, there is the presence of commercial cultivars (JONES; BRANDON, 1998). Thus, in order to start the cultivation and support the breeding of this plant, expeditions were carried out to collect specimens in various municipalities in the state of Pernambuco (QUEIROZ, 2012).

Some studies have evaluated the response of species of Desmanthus to cutting (ADJEI; PITMAN, 1993; TRUJILLO et al., 1996; GONZALEZ-V et al., $2005)$, but there is no record of work of this nature in the northeast of Brazil. According to Fontenele et al. (2009), further studies on the management of these species are required.

The study of the morphological and productive behavior of these genotypes when grown and managed under cutting is of great importance, since it will allow the selection of materials with desirable characteristics to forage plants such as good capacity for regrowth, persistence, higher leaf/ stem ratio and greater forage yield.

The cutting height is an important aspect in the management of forage legumes, since it affects the regrowth rate (SHEN et al., 2013), the dry matter yield (KARIN et al., 1991), the forage quality and the persistence (TRUJILLO et al., 1996; MEURIOT et al., 2005) of the forage plant in the yield system. Genotypes of the same species may also respond differently to cutting intensities.

The full understanding of the responses of forage plants to cutting is important to define management strategies for them. Hence, considering that the "jureminha" behavior when grown and managed under cutting in the northeastern semi-arid is still unkown, the objective of this study was to evaluate morphological characteristics, as well as the productivity of five genotypes of Desmanthus spp. submitted to two cutting intensities in the semi-arid region of Pernambuco.

\section{MATERIAL AND METHODS}

The research was conducted in the experimental field of the Academic Unit of Serra Talhada (UAST) of the Federal Rural University of Pernambuco, during the period from March to December 2014. The local climate, according to Köppen classification adapted to Brazil, is BSwh' type, called semi-arid, hot and dry, with summer rains, annual thermal averages exceeding $25^{\circ} \mathrm{C}$ and average annual rainfall of $650 \mathrm{~mm}$ year $^{-1}$ with irregular rainfall (MELO et al., 2008). The rainfall and the average air temperature in the year 2014 are shown in Figure 1.

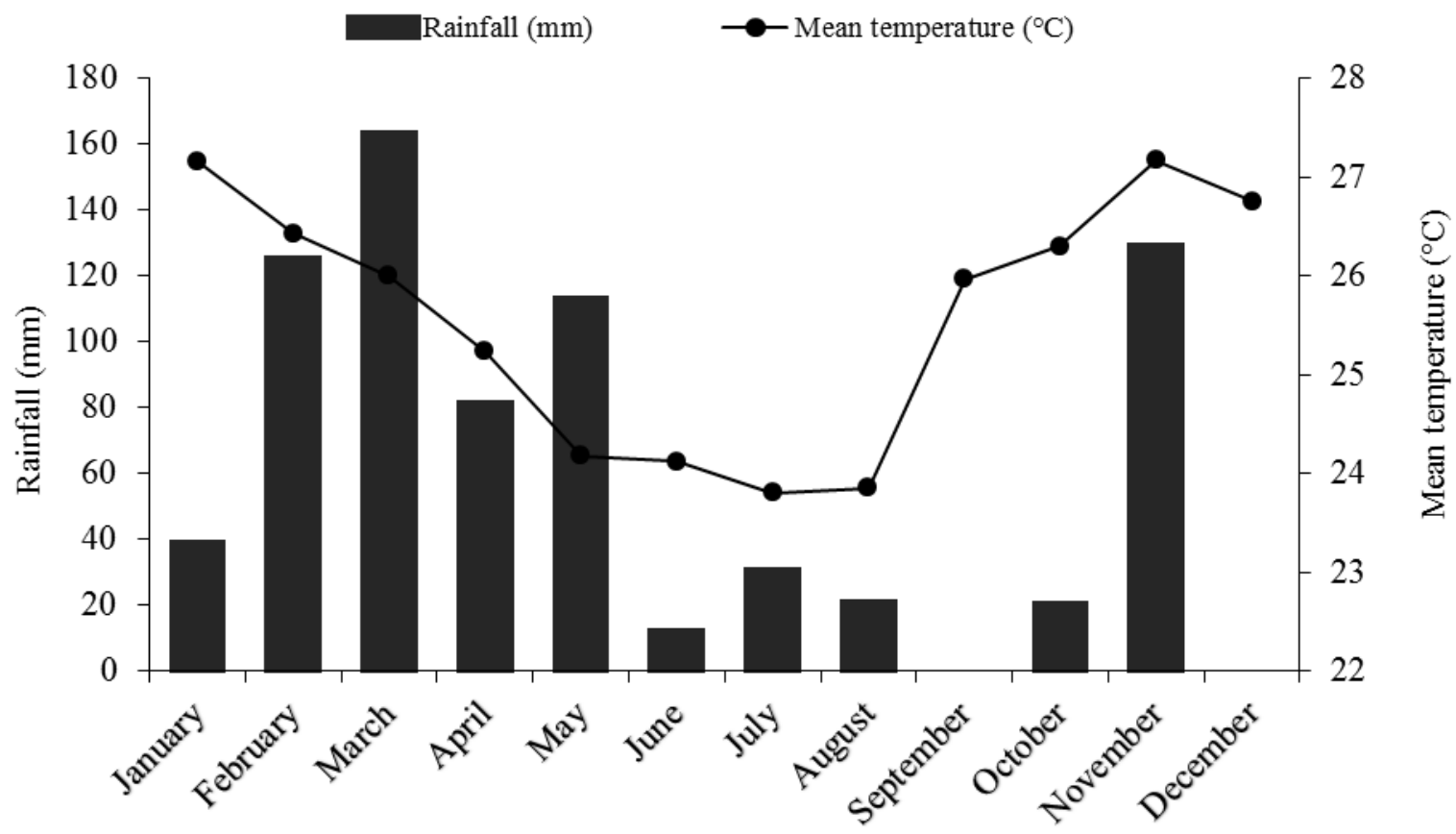

Figure 1. Rainfall (mm) and average temperature $\left({ }^{\circ} \mathrm{C}\right)$ throughout the year 2014. 
It were studied the effects of two cutting intensities $(20$ and $40 \mathrm{~cm})$ on the morphological and productive characteristics of five genotypes of "jureminha" (Desmanthus spp.). The treatments were randomized in blocks and distributed in a split plot design with three replications. The main plots consisted of genotypes and the subplots consisted of cutting intensities.

Three genotypes of "jureminha" came from collections in three municipalities of Pernambuco, namely Santa Cruz do Capibaribe, Caetés and Petrolina, and correspond to the F1 generation of these plants. These were named $7 \mathrm{G}, 31 \mathrm{D}$ and $50 \mathrm{~J}$, respectively, in relation to the municipalities mentioned above. The other two genotypes came from the Germplasm Bank of Desmanthus of the Embrapa Tabuleiros Costeiros in Aracaju - SE and have an Australian origin. These were named 10AU and $13 \mathrm{AU}$.

Before planting, the soil of the experimental field was prepared using a disk harrow coupled to a tire tractor. Chemical and physical analyses of soil samples of the experimental area, at a depth of 0-20 $\mathrm{cm}$, were performed. The soil had the following chemical characteristics: $\mathrm{pH}$ (water) = 7.9; $\mathrm{P}$ $\left(\right.$ Mehlich I) $=>348 \mathrm{mg} \mathrm{dm}^{-3} ; \mathrm{K}^{+}=0.39 \mathrm{cmol}_{\mathrm{c}} \mathrm{dm}^{-3}$; $\mathrm{Ca}^{2+}=3.20 \mathrm{cmol}_{\mathrm{c}} \mathrm{dm}^{-3} ; \mathrm{Mg}^{2+}=0.10 \mathrm{cmol}_{\mathrm{c}} \mathrm{dm}^{-3}$; $\mathrm{Al}^{3+}=0.00$; organic matter $=33 \mathrm{~g} \mathrm{~kg}^{-1}$. Physically, the soil has shown: $102.6 \mathrm{~g} \mathrm{~kg}^{-1}$ clay, $54.8 \mathrm{~g} \mathrm{~kg}^{-1}$ silt and $842 \mathrm{~g} \mathrm{~kg}^{-1}$ sand. No fertilization was performed, whether mineral or organic.

The seedlings obtained from the seeds were used for planting. The plant spacing was $0.5 \mathrm{~m} \mathrm{x} 0.5$ $\mathrm{m}$; each plot had 32 plants. The subplots were composed of 16 plants, with an area of $4 \mathrm{~m}^{2}$. The useful area of the plot comprised the four central plants of each subplot, with $1 \mathrm{~m}^{2}$ area. During the experiment, the plots were drip-irrigated daily. The amount of water provided was based on the annual average daily evapotranspiration. A water depth of $5.5 \mathrm{~mm}$ was used at intervals of one day, being suspended whenever rain events occurred. The water used had electrical conductivity of $1.86 \mathrm{dS} \mathrm{m}^{-1}$, classified as C3, with high salinity, according to the classification of Richards (1954).

Ninety days after planting, the first cutting was performed, in June 2014, at which time the treatments were applied (cutting intensities). Since then, three new cuttings were made every 60 days. The cuttings were made from ground level to the height defined for each treatment, 20 or $40 \mathrm{~cm}$, stretching the branches of the plant upright.

At each cutting, morphological and productive evaluations were performed. The morphological characteristics studied were plant height, stem diameter, canopy diameter, number of leaves per branch, leaf area index (LAI) and light interception. The plant height was achieved by means of measuring tape, from ground level to the apex of the plants, without stretching the branches; stem diameter was taken in the basal part of the plant, just above the ground, by means of $150 \mathrm{~mm}$ digital caliper; the average canopy diameter was obtained from two measurements in the plant canopy, which were taken in two perpendicular axes on the plant, and then the arithmetic average was calculated; the count of the number of leaves was performed in a representative branch of each plant of the useful plot; LAI and light interception was determined by a canopy analyzer AccuPAR LP-80 (Decagon Devices Inc. ${ }^{\circledR}$ ). The measurements with the analyzer were made at four points above and four points below the canopy in each subplot, in clear days, close to noon.

The productive characteristics estimated were leaves, stem and pod yield, besides the total yield and the forage yield, which was obtained by the sum of the of leaves and stems yield. After each cutting, the collected material was separated into pods (with seeds), leaf and stem. Thus, it was also determined the leaf stem $-{ }^{1}$ ratio, through the division of the value obtained on the dry weight fraction of the leaf by the dry weight of the stem fraction, and the pod stem ${ }^{-1}$ ratio, by dividing the dry weight fraction of the pod by the dry weight of the stem fraction. After this separation, the material of each fraction was subjected to drying in a forced circulation oven at a temperature of $55^{\circ} \mathrm{C}$ for a period of 72 hours. After this period, the material was weighed in semianalytical balance with a precision of $0.01 \mathrm{~g}$, for determining the dry weight of each of the fractions and estimating the productive characteristics mentioned.

The data were submitted to analysis of variance using the procedure PROC MIXED (LITTELL et al., 1998) of SAS (SAS, 1999). The data of the leaves yield, stems yield and forage yield were transformed to $\log (\mathrm{x})$ to meet the normality assumption. As for the data of stem diameter, canopy diameter, the number of leaves per branch and plant height, they were transformed to root (x). It was considered the effects of genotypes, cutting intensities and cuttings, besides to the effect of the experimental blocks. The cuttings were considered repeated measures over time. The effect of blocks was random. The method of least squares (LSMEANS) was used to compare means between the genotypes and cuttings, by PDIFF set to Tukey's test. The F-test was used to compare the means of the cutting intensities. All differences were considered significant at $5 \%$ probability.

\section{RESULTS AND DISCUSSION}

\section{Morphological characteristics}

In relation to plant height and stem diameter, there was a significant effect $(\mathrm{P}<0.05)$ of the interaction genotypes $\mathrm{x}$ cutting intensities (Table 1). 
The genotypes 50J, 10AU and 13AU had lower heights when managed with $40 \mathrm{~cm}$ cuttings. The fact that the heights of the genotypes $50 \mathrm{~J}$ and $10 \mathrm{AU}$, in the intensity of $40 \mathrm{~cm}$, were lower than the applied intensity may be due to the weight of the branches, where, to the extent that the plant was developing and branches grew, there was a tendency for these to be directed to the sides.

Regarding the stem diameter, it was only reduced in genotype $50 \mathrm{~J}$, when cut at $40 \mathrm{~cm}$ above ground level. In the intensity of $20 \mathrm{~cm}$, the genotype
31D showed higher stem diameter than the genotype $13 \mathrm{AU}$, while in the intensity of $40 \mathrm{~cm}$, the genotypes 7G, 31D and 10AU showed greater stem diameter than the genotype 50J (Table 1). According to Paludo et al. (2012), stem diameter is a contributing factor in the biomass yield of plants, where the larger the diameter, the higher the yield. These same authors, when assessing the guandu bean (Cajanus cajan (L.) Millsp) under different cutting heights, found that the plants cut with greater height (lower intensity) showed greater stem diameter.

Table 1. Plant height and stem diameter in different genotypes of "jureminha" (Desmanthus spp.) according to the cutting intensities (CI).

\begin{tabular}{|c|c|c|c|c|c|c|}
\hline \multirow{4}{*}{ Genotypes } & \multicolumn{3}{|c|}{ Plant height (cm) } & \multicolumn{3}{|c|}{ Stem diameter $(\mathrm{mm})$} \\
\hline & \multicolumn{2}{|c|}{$\mathrm{CI}(\mathrm{cm})$} & \multirow{2}{*}{ Mean } & \multicolumn{2}{|c|}{$\mathrm{CI}(\mathrm{cm})$} & \multirow{2}{*}{ Mean } \\
\hline & 20 & 40 & & 20 & 40 & \\
\hline & \multicolumn{3}{|c|}{$\mathrm{cm}$} & \multicolumn{3}{|c|}{$\mathrm{Mm}$} \\
\hline $7 \mathrm{G}$ & $50.86 \mathrm{aA}$ & $57.13 \mathrm{aA}$ & 53.99 & $9.85 \mathrm{ABa}$ & $9.13 \mathrm{Aa}$ & 9.49 \\
\hline $50 \mathrm{~J}$ & $52.00 \mathrm{aA}$ & $32.27 \mathrm{bC}$ & 42.13 & $8.82 \mathrm{ABa}$ & 7.19Bb & 8.00 \\
\hline $31 \mathrm{D}$ & $56.06 \mathrm{aA}$ & $61.18 \mathrm{aA}$ & 58.62 & $10.25 \mathrm{Aa}$ & $9.24 \mathrm{Aa}$ & 9.74 \\
\hline $10 \mathrm{AU}$ & $46.74 \mathrm{aAB}$ & $35.99 \mathrm{bC}$ & 41.36 & 8.89ABa & $8.84 \mathrm{Aa}$ & 8.87 \\
\hline $13 \mathrm{AU}$ & $39.49 \mathrm{bB}$ & $49.38 \mathrm{aB}$ & 44.43 & $8.20 \mathrm{Ba}$ & $8.48 \mathrm{ABa}$ & 8.34 \\
\hline Mean & 49.03 & 47.19 & & 9.20 & 8.58 & \\
\hline Standard error & \multicolumn{3}{|c|}{4.99} & \multicolumn{3}{|c|}{0.01} \\
\hline
\end{tabular}

Means followed by the same uppercase letter in the column do not differ by the Tukey test at $5 \%$ probability.

Means followed by the same lowercase letter in the row do not differ by the Tukey test at $5 \%$ probability.

There was a significant effect $(\mathrm{P}<0.05)$ of the interaction genotypes $\mathrm{x}$ cuttings to the $\mathrm{pod} / \mathrm{stem}$ ratio and the number of leaves per branch (Table 2). The $\mathrm{pod} / \mathrm{stem}$ ratio decreased after successive cuts for the genotypes $7 \mathrm{G}, 50 \mathrm{~J}$ and $13 \mathrm{AU}$. In genotypes $31 \mathrm{D}$ and $10 \mathrm{AU}$, the $\mathrm{pod} / \mathrm{stem}$ ratio remained constant over cuttings. When comparing the genotypes within the cuttings, in general, genotypes $10 \mathrm{AU}$ and $13 \mathrm{AU}$ had the highest pod/stem ratios in the cuttings, while genotypes $7 \mathrm{G}$ and $50 \mathrm{~J}$ expressed the lowest pod/stem ratios. According to Allen et al. (2011), forage is defined as the plant parts considered edible to animals, excluding grains. Thus, the pod/stem ratio may be indicative of the forage yield potential, where genotypes with lower pod/stem ratio values have a trend for higher forage yield. Throughout the cuttings, it can be seen that there is a general trend for a reduction of the pod/stem ratio for genotypes $7 \mathrm{G}, 31 \mathrm{D}$ and 50J.

Table 2. Pod stem ${ }^{-1}$ ratio and the number of leaves per branch in different genotypes of "jureminha" (Desmanthus spp.) along three cuts 60 -day intervals.

\begin{tabular}{|c|c|c|c|c|c|c|c|c|}
\hline \multirow{3}{*}{ Genotypes } & \multicolumn{4}{|c|}{ Pod stem ${ }^{-1}$ ratio } & \multicolumn{4}{|c|}{ Number of leaves per branch } \\
\hline & \multicolumn{3}{|c|}{ Cuttings } & \multirow{2}{*}{ Mean } & \multicolumn{3}{|c|}{ Cuttings } & \multirow{2}{*}{ Mean } \\
\hline & $1^{\mathrm{o}}$ & $2^{\circ}$ & $3^{\circ}$ & & $1^{\mathrm{o}}$ & $2^{\circ}$ & $3^{\circ}$ & \\
\hline $7 \mathrm{G}$ & $0.93 \mathrm{Ca}$ & $0.79 \mathrm{Ca}$ & $0.34 \mathrm{Bb}$ & 0.68 & 16.17Aa & $13.00 \mathrm{Ab}$ & $13.42 \mathrm{Ab}$ & 14.19 \\
\hline $50 \mathrm{~J}$ & $1.64 \mathrm{Ba}$ & $1.31 \mathrm{BCa}$ & $0.60 \mathrm{Bb}$ & 1.18 & 14.38Aa & $8.79 \mathrm{Bc}$ & $11.17 \mathrm{Ab}$ & 11.44 \\
\hline $31 \mathrm{D}$ & $1.60 \mathrm{Ba}$ & $1.14 \mathrm{Ca}$ & $1.41 \mathrm{Aa}$ & 1.38 & $11.00 \mathrm{Bb}$ & $11.21 \mathrm{Ab}$ & $14.71 \mathrm{Aa}$ & 12.31 \\
\hline
\end{tabular}

Means followed by the same uppercase letter in the column do not differ by the Tukey test at $5 \%$ probability. Means followed by the same lowercase letter in the row do not differ by the Tukey test at $5 \%$ probability. 
T. B. CALADO et al.

Table 2. Continuation.

\begin{tabular}{|c|c|c|c|c|c|c|c|c|}
\hline \multirow{3}{*}{ Genotypes } & \multicolumn{4}{|c|}{ Pod stem $^{-1}$ ratio } & \multicolumn{4}{|c|}{ Number of leaves per branch } \\
\hline & \multicolumn{3}{|c|}{ Cuttings } & \multirow{2}{*}{ Mean } & \multicolumn{3}{|c|}{ Cuttings } & \multirow{2}{*}{ Mean } \\
\hline & $1^{\mathrm{o}}$ & $2^{\circ}$ & $3^{\circ}$ & & $1^{\mathrm{o}}$ & $2^{\circ}$ & $3^{\circ}$ & \\
\hline $10 \mathrm{AU}$ & $2.33 \mathrm{Aa}$ & 2.64Aa & $1.78 \mathrm{Aa}$ & 2.25 & $9.67 \mathrm{BCa}$ & $7.38 \mathrm{Bb}$ & $10.60 \mathrm{Ba}$ & 9.21 \\
\hline $13 \mathrm{AU}$ & $2.27 \mathrm{Aa}$ & $1.56 \mathrm{Bb}$ & $1.62 \mathrm{Ac}$ & 1.82 & $7.56 \mathrm{Ca}$ & 7.21Ba & $9.71 \mathrm{Ca}$ & 8.16 \\
\hline Mean & 1.75 & 1.49 & 1.15 & & 11.75 & 9.52 & 11.92 & \\
\hline Standard error & & 0.04 & & & & 0.77 & & \\
\hline
\end{tabular}

Means followed by the same uppercase letter in the column do not differ by the Tukey test at $5 \%$ probability.

Means followed by the same lowercase letter in the row do not differ by the Tukey test at $5 \%$ probability.

For the number of leaves per branch, genotypes showed different behaviors between cuttings. For $7 \mathrm{G}$ and $50 \mathrm{~J}$, the number of leaves was higher $(\mathrm{P}<0.005)$ in the 1 st cutting compared to the 2nd and $3 \mathrm{rd}$, while for $31 \mathrm{D}$, the number of leaves was higher $(\mathrm{P}<0.005)$ in the 3 rd cutting. For $10 \mathrm{AU}$ and $13 \mathrm{AU}$, the number of leaves remained somehow constant in the successive cuttings, with the exception of 10AU, which in the 2 nd cutting showed a decrease in the number of leaves per branch. Within the cuttings, in general, genotypes $7 \mathrm{G}, 50 \mathrm{~J}$ and $31 \mathrm{D}$ had a greater number of leaves than genotypes 10AU and 13AU (Table 2).

A significant effect $(\mathrm{P}<0.05)$ was observed of genotypes for canopy diameter. Genotypes $7 \mathrm{G}$ and 31D had higher canopy diameter than the other genotypes, averaging $90.74 \mathrm{~cm}$ and $85.26 \mathrm{~cm}$, respectively. The canopy diameter shown by the other genotypes was $75.95,69.79$, and $69.47 \mathrm{~cm}$ for $50 \mathrm{~J}, 10 \mathrm{AU}$ and $13 \mathrm{AU}$, respectively.

The cutting intensity significantly influenced $(\mathrm{P}<0.05)$ the canopy diameter (Figure 2). It was observed that in the intensity of $20 \mathrm{~cm}$, the canopy diameter was higher than that obtained in the intensity of $40 \mathrm{~cm}$. This result suggests that the plants harvested at lower height tend to have a more open growth habit, increasing, consequently, their canopy dimensions. Probably, in the plants cut at lower height, there was elimination of the apical meristem with consequent breaking of the apical dominance. Thus, there was a stimulus for the emergence and growth of side shoots.

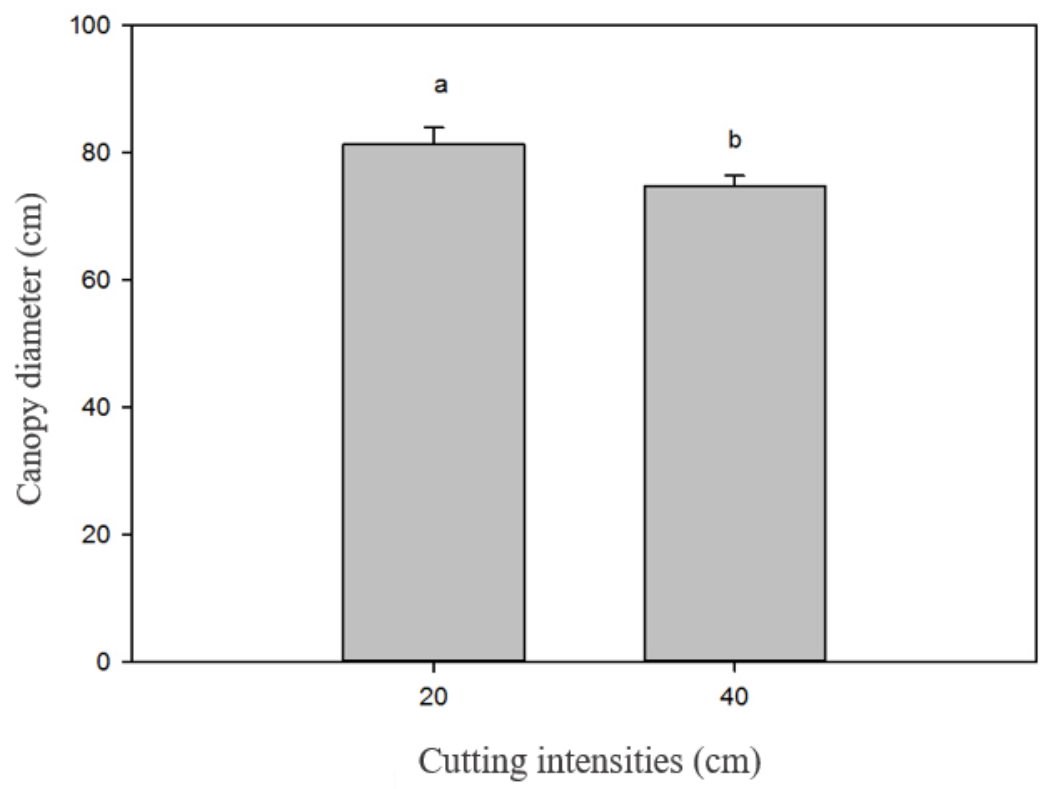

Figure 2. Canopy diameter of "jureminha" (Desmanthus spp.) plants according to the cutting intensities. Same letters on the error bar do not differ $(\mathrm{P}>0.05)$ by $\mathrm{F}$ test.

There was a significant effect $(\mathrm{P}<0.05)$ of the cuttings on the leaf area index (LAI), light interception (LI), plant height, number of leaves per branch, stem diameter and canopy diameter
(Table 3). LAI, light interception and plant height were significantly higher in the third cutting in relation to the first and second cuttings. For the number of leaves per branch, the highest average 
values were observed in the first and third cuttings. The stem diameter increased in the 2nd and 3rd cutting when compared to the $1 \mathrm{st}$ cutting. The canopy diameter decreases only in the second cutting.

The genotypes have shown an ability to recover after four consecutive cuttings (including the uniformity cut), maintaining the stable yield of leaves and canopy diameter, besides increasing the leaf area index and thus the light interception. These factors are of great importance for the forage yield and are closely related to each other, considering that increased leaf yield contributes to the increased canopy diameter, which also contributes to increases in the leaf area index, and consequently in the light interception.

The fact that the number of leaves and the canopy diameter have shown a reduction in the second cutting may be related to an attack of leafcutting ants, which occurred in one of the blocks, just prior to the second cutting, affecting all plots in that block. The increased stem diameter observed, from the first to the third cutting, was associated with the age of plants and successive cuttings, which naturally promotes the thickening of their stem.

Table 3. Morphological characteristics in genotypes of "jureminha" (Desmanthus spp.) along three cuts 60-day intervals.

\begin{tabular}{|c|c|c|c|c|c|c|}
\hline Cutting & Leaf area & Light & Height plant & $\mathrm{N}^{\circ}$ of leaves & Stem diameter & $\begin{array}{l}\text { Canopy } \\
\text { diameter }\end{array}$ \\
\hline & & & $\mathrm{cm}$ & & $\mathrm{mm}$ & $\mathrm{cm}$ \\
\hline $1^{\mathrm{o}}$ & $1.30 \mathrm{~b}$ & $45.56 \mathrm{~b}$ & $44.13 b$ & $11.80 \mathrm{a}$ & $8.25 b$ & $80.65 \mathrm{a}$ \\
\hline $2^{\circ}$ & $1.27 \mathrm{~b}$ & $46.65 b$ & $44.42 b$ & $9.58 b$ & $8.98 \mathrm{a}$ & $71.81 \mathrm{~b}$ \\
\hline $3^{\circ}$ & $1.95 \mathrm{a}$ & $58.60 \mathrm{a}$ & $55.77 \mathrm{a}$ & $11.93 \mathrm{a}$ & $9.47 \mathrm{a}$ & $82.28 \mathrm{a}$ \\
\hline Mean & 1.50 & 50.27 & 48.11 & 11.10 & 8.90 & 78.25 \\
\hline $\begin{array}{l}\text { Standard } \\
\text { error }\end{array}$ & 0.01 & 9.71 & 0.04 & 0.03 & 0.02 & 0.08 \\
\hline
\end{tabular}

Means followed by the same letter do not differ by the Tukey test at $5 \%$ probability.

According to Silva et al. (2010), the number of leaves present in a plant is related to the potential plant biomass accumulation, which is an important feature for recommending the use of forage species. In addition to the yield potential, forage plants that produce increased amounts of leaves tend to provide better-quality forage, considering that in the leaves there is a higher concentration of nutrients for the animal.

The canopy dimensions interfere with the performance of physiological processes and in many cases are used as indicators of the capacity of a plant to compete for other resources (LEITES et al., 2012). Nutto (2001) explains that this variable is directly related to the growth and biomass yield of a plant. Therefore, it is possible that plants with larger canopy diameter, as well as an increased number of leaves on the branches, produce higher amounts of forage, with better quality. In the management of consecutive and regular cuttings, the analysis of variables related to the size of the canopy aims to provide information that reflects the potential capacity for regrowth of the forage species that was subject to such management.

\section{Productive characteristics}

There was a significant effect $(\mathrm{P}<0.05)$ of genotypes for leaf yield, forage yield and pod yield (Table 4). For leaf yield, the genotype $7 \mathrm{G}$ was superior to genotypes $50 \mathrm{~J}, 10 \mathrm{AU}$ and $13 \mathrm{AU}$, but did not differ from 31D. The genotype 13AU was inferior to the others regarding leaf yield, except for $10 \mathrm{AU}$. For forage yield, genotype $7 \mathrm{G}$ was superior to the others, except for $31 \mathrm{D}$, which did not differ from 50J. Genotypes 10AU and 13AU had the lowest forage yield. As for pod yield, genotypes 31D and 10AU showed higher yield of pods than genotypes $7 \mathrm{G}$ and $50 \mathrm{~J}$. The genotype $13 \mathrm{AU}$ did not differ from the others. 
T. B. CALADO et al.

Table 4. Leaves, forage and pod yield in different genotypes of "jureminha” (Desmanthus spp.).

\begin{tabular}{cccc}
\hline \multirow{2}{*}{ Genotypes } & Leaves yield & Forage yield & Pod yield \\
\cline { 2 - 4 } & & $\mathrm{kg} \mathrm{DM} \mathrm{ha}{ }^{-1}$ & $342.75 \mathrm{~b}$ \\
$70 \mathrm{~J}$ & $508.80 \mathrm{a}$ & $1102.06 \mathrm{a}$ & $393.92 \mathrm{~b}$ \\
31D & $359.44 \mathrm{~b}$ & $771.31 \mathrm{~b}$ & $578.79 \mathrm{a}$ \\
$10 \mathrm{AU}$ & $414.58 \mathrm{ab}$ & $867.23 \mathrm{ab}$ & $560.71 \mathrm{a}$ \\
$13 \mathrm{AU}$ & $293.56 \mathrm{bc}$ & $552.41 \mathrm{c}$ & $464.11 \mathrm{ab}$ \\
\hline Mean & $258.39 \mathrm{c}$ & $509.68 \mathrm{c}$ & 468.05 \\
\hline
\end{tabular}

Means followed by the same letter in the column do not differ by the Tukey test at $5 \%$ probability.

The genotypes coming from Pernambuco (7G, 50J and 31D) showed higher yield of leaves and forage in relation to those of Sergipe (10AU and 13AU), from Australia. The genotypes derived from the Agreste region, 7G (Santa Cruz do Capibaribe) and 31D (Caetés), stood out compared to the others, although all of these genotypes have been collected in semi-arid environments. Based on these results, it is observed that the genotypes that were not derived from Pernambuco (10AU and 13AU) expressed a lower yield of leaves and forage compared to the native ones.

Genotypes 31D and 10AU produced more pods than genotypes $7 \mathrm{G}$ and $50 \mathrm{~J}$, but did not differ from 13AU. Throughout the experiment, it was found through in loco observations that the genotypes did not show uniformity in the maturation of their fruits and these, in turn, had shown dehiscence. In this case, the genotypes $7 \mathrm{G}$ and 50J had most of their pods open, with the release of seeds showing a precocity in relation to the others, which contributed to the reduction of the dry weight of the pods (yield) at the time of the cuttings. Hence, the precocity of the opening of pods in these genotypes may facilitate the harvest management, yielding a higher proportion of the fractions that led to a better quality of forage (leaf and stem).

The total yield and the yield of leaves, stem, pod and forage differed $(\mathrm{P}<0.05)$ between the cuttings made (Table 5 ). It was found that, with the exception of the pod yield, all previously cited variables showed higher yields in the third cutting. The pod yield was higher in the first cutting. In the first and second cuttings, the yield of leaves, stem and forage did not differ statistically. Total yield was lower in the second cutting, which may have the attack of ants as a cause, as mentioned above, and the lower availability of water due to the reduced rainfall in the period before the second cutting.

Table 5. Total, leaves, stems, pods and forage yield in different genotypes of "jureminha" (Desmanthus spp.) along three cuts 60-day intervals.

\begin{tabular}{cccccc}
\hline \multirow{2}{*}{ Cuttings } & Total yield & Leaves yield & Stems yield & Pod yield & Forage yield \\
& & & $\mathrm{kg} \mathrm{DM} \mathrm{ha}{ }^{-1}$ & & \\
\cline { 2 - 5 } & $1240.10 \mathrm{~b}$ & $337.87 \mathrm{~b}$ & $350.16 \mathrm{~b}$ & $552.08^{\mathrm{a}}$ & $688.02 \mathrm{~b}$ \\
$1^{\mathrm{o}}$ & $1063.29 \mathrm{c}$ & $330.26 \mathrm{~b}$ & $315.49 \mathrm{~b}$ & $417.54 \mathrm{~b}$ & $645.75 \mathrm{~b}$ \\
$2^{\mathrm{o}}$ & $1360.01 \mathrm{a}$ & $418.07 \mathrm{a}$ & $494.44 \mathrm{a}$ & $447.51 \mathrm{~b}$ & $912.51 \mathrm{a}$ \\
\hline Mean & 1221.13 & 362.06 & 386.70 & 472.37 & 748.76 \\
Standard error & 115.42 & 0.01 & 0.01 & 29.23 & 0.02 \\
\hline
\end{tabular}

Means followed by the same letter in the column do not differ by the Tukey test at $5 \%$ probability.

During the conduct of the experiment, it was observed in loco that the bundleflower plants showed recovery capacity at each cutting. According to
Marcelino et al. (2006), the ability of a forage plant to support the performance of successive cuttings may be related to greater efficiency in the renewal of 
tissues, which results in increased forage yield.

Throughout the cuttings, an increase in the stem yield in relation to pod yield was observed (Table 5), which explains the decrease of the pod/ stem ratio for the genotypes $7 \mathrm{G}, 50 \mathrm{~J}$ and $13 \mathrm{AU}$ (Table 2). In this sense, it is important to highlight that the process of yield/maturing of pods in genotypes did not occur uniformly. At the time of cutting, the pods could have already been opened and released seeds (influence on weight), which in turn influenced the pod/stem ratio behavior. Notwithstanding, what was observed for this variable is that as the cuttings were performed, there was a reduction in pod yield and increased stem yield. These facts may be related to the greater water availability during the rainy season, leading to reduced pod yield. Possibly, the plants started to concentrate photoassimilates for the yield of vegetative organs (leaf and stem), making the yield of pods limited and/or delaying their yield.
During the evaluation period, it was observed that in the first interval, between the uniformity cut and the first cutting, there was an accumulated rainfall of $53.4 \mathrm{~mm}$. In the interval between the first and second cuttings, the rainfall was $17.2 \mathrm{~mm}$. In the interval between the second and third cuttings, the rainfall was $126.1 \mathrm{~mm}$ (Figure 1). Observing the behavior of genotypes for total yield, leaf yield, forage yield and stem yield, it is clear that, even with the regular supply of water for all genotypes and although bundleflower is a species that is resistant to low levels of rainfall, there was a positive response of these genotypes to the increasing amount of rainfall in the intervals between the cuttings for the variables mentioned above.

The cutting intensity significantly influenced $(\mathrm{P}<0.05)$ the forage yield. The forage yield obtained in plants cut at $20 \mathrm{~cm}$ was higher than in relation to the yield obtained in those submitted to the intensity of $40 \mathrm{~cm}$ (Figure 3).

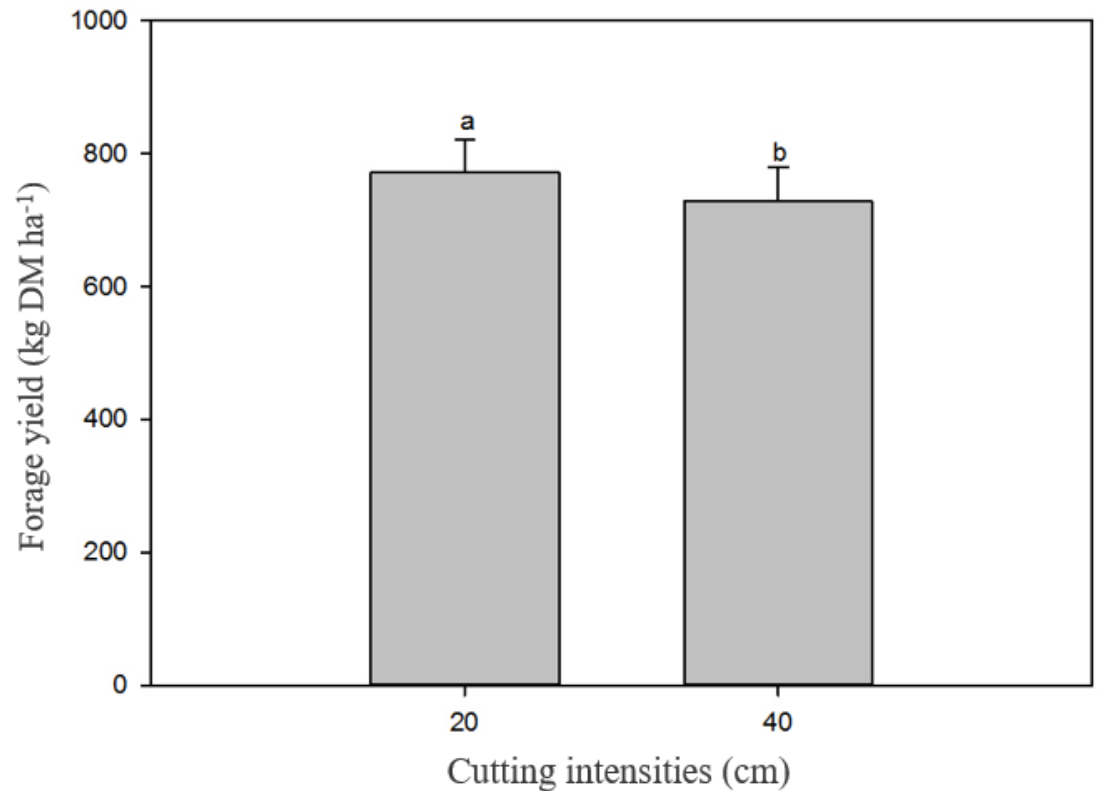

Figure 3. Forage yield, in $\mathrm{kg} \mathrm{DM} \mathrm{ha}^{-1}$, of "jureminha" (Desmanthus spp.) plants according to the cutting intensities, Serra Talhada-PE. Same letters on the error bar do not differ $(\mathrm{P}>0.05)$ by $F$ test.

Possibly, there was a greater removal of tissues and meristems in the highest cutting intensity, which led to the stimulation of forage yield of the bundleflower. This increase in yield is related to the fact that, in the highest cutting intensity, the apical meristem may have been eliminated, which led to the stimulation of the emergence of new side shoots. This can also be associated with the enhanced light condition to which such plants were exposed during the removal of higher amounts of biomass. Taiz and Zeiger (1998) argue that stem elongation as a function of incident radiation is an adaptive response of plants to maximize the interception of light. Therefore, by reducing shading and allowing more radiation on the remaining meristems, there was a greater stimulus for the growth and development of new shoots, thus contributing to the increase in forage yield.

For stem yield, there was a significant effect $(\mathrm{P}<0.05)$ for the interaction between genotypes and cutting intensities (Table 6). In the intensity of 20 $\mathrm{cm}$, genotypes $7 \mathrm{G}$ and $31 \mathrm{D}$ showed higher stem yield than the others. In the intensity of $40 \mathrm{~cm}$, genotypes $7 \mathrm{G}, 50 \mathrm{~J}$ and $31 \mathrm{D}$ showed higher stem yield than the others. The stem yield in the intensity of $20 \mathrm{~cm}$ did not differ from that obtained in the intensity of $40 \mathrm{~cm}$ only for genotypes $50 \mathrm{~J}$ and $10 \mathrm{AU}$. For the other genotypes, the yield of stems was higher in the intensity of $20 \mathrm{~cm}$. 
T. B. CALADO et al.

Table 6. Stem yield and leaf stem-1 ratio in genotypes of "jureminha" (Desmanthus spp.) according to the cutting intensities.

\begin{tabular}{|c|c|c|c|c|c|c|}
\hline \multirow{4}{*}{ Genotypes } & \multicolumn{3}{|c|}{ Stem yield } & \multicolumn{3}{|c|}{ Leaf stem-1 ratio } \\
\hline & \multicolumn{2}{|c|}{ Cutting intensities } & \multirow{3}{*}{ Mean } & \multicolumn{2}{|c|}{ Cutting intensities } & \multirow{3}{*}{ Mean } \\
\hline & $20 \mathrm{~cm}$ & $40 \mathrm{~cm}$ & & & & \\
\hline & \multicolumn{2}{|c|}{$\mathrm{kg} \mathrm{DM} \mathrm{ha}^{-1}$} & & & & \\
\hline $7 \mathrm{G}$ & $664.13 \mathrm{Aa}$ & $546.01 \mathrm{Ab}$ & 605.07 & $0.80 \mathrm{Ba}$ & $1.00 \mathrm{Ba}$ & 0.90 \\
\hline $50 \mathrm{~J}$ & $351.29 \mathrm{Ba}$ & $472.43 \mathrm{Aa}$ & 411.86 & $1.10 \mathrm{Aa}$ & $0.90 \mathrm{Ba}$ & 1.00 \\
\hline $31 \mathrm{D}$ & $537.06 \mathrm{Aa}$ & $368.24 \mathrm{Ab}$ & 452.65 & $0.90 \mathrm{ABa}$ & $1.10 \mathrm{ABa}$ & 1.00 \\
\hline $10 \mathrm{AU}$ & $279.40 \mathrm{Ba}$ & $238.29 \mathrm{Ba}$ & 258.84 & $1.10 \mathrm{Aa}$ & $1.20 \mathrm{Aa}$ & 1.20 \\
\hline $13 \mathrm{AU}$ & $290.26 \mathrm{Ba}$ & $212.32 \mathrm{Bb}$ & 251.29 & $0.90 \mathrm{ABb}$ & $1.30 \mathrm{Aa}$ & 1.10 \\
\hline Mean & 424.43 & 367.46 & & 1.00 & 1.10 & \\
\hline Standard error & & & & & 0.01 & \\
\hline
\end{tabular}

Means followed by the same uppercase letter in the column do not differ by the Tukey test at $5 \%$ probability.

Means followed by the same lowercase letter in the row do not differ by the $\mathrm{F}$ test at $5 \%$ probability.

The leaf stem $^{-1}$ ratio was also influenced by the effect of the interaction cutting intensity $x$ genotypes (Table 6). For cutting intensities, there were significant differences only for genotype 13AU, which showed a higher leaf stem $^{-1}$ ratio when cut in the intensity of $40 \mathrm{~cm}$. In the cutting intensity of $20 \mathrm{~cm}$, genotypes 50J and 10AU had higher leaf/ stem ratio than the genotype $7 \mathrm{G}$. Genotypes $31 \mathrm{D}$ and $13 \mathrm{AU}$ did not differ from these genotypes. However, in the cutting intensity of $40 \mathrm{~cm}$, genotypes $10 \mathrm{AU}$ and $13 \mathrm{AU}$ had higher leaf stem $^{-1}$ ratio than genotypes $7 \mathrm{G}$ and 50J, but did not differ from 31D.

The leaf stem $^{-1}$ ratio is a feature that varies depending on the production of the fractions of leaves and stems and, for forage plants, it is important that it shows values greater than 1 , given that in this case there is always a larger amount of leaves than stems. These variations influence the nutritional value of the forage, since the chemical composition of each of the fractions may differ widely, because, generally, in leaves, the concentration of digestible nutrients is larger than in the stem.

Overall, it was observed that variations of the leaf/stem ratios of the genotypes submitted to cutting intensities were small, except for the genotype 13AU, which, in the intensity of $40 \mathrm{~cm}$, obtained a much higher value when compared to the intensity of $20 \mathrm{~cm}$. The leaf $/ \mathrm{stem}$ ratio exerts great influence with regard to animal nutrition. Teixeira et al. (2010) report that the leaf/stem ratio existing in a legume may interfere with the forage intake by animals, as they prefer to feed on more tender material and of better nutritional value, in this case, the leaves.

Araújo et al. (2008) state that the behavior of a forage plant results from the interaction of its genetic potential with the environment. The authors mention that to maximize the forage production potential, it is necessary to adapt the plant to the environment, either through breeding or through partial changes in the environment. The latter can be achieved by cutting management. Therefore, it can be seen that for the conditions of this study, the genotypes derived from Pernambuco showed the best results for the variables related to production and growth, suggesting higher regrowth ability of these genotypes when subjected to cutting management.

\section{CONCLUSIONS}

Genotypes of Desmanthus spp. should be cut at $20 \mathrm{~cm}$, at the expense of the $40 \mathrm{~cm}$ cutting, to stimulate growth and forage yield.

The morphological and productive differences shown between genotypes of Desmanthus spp., especially $7 \mathrm{G}$ and $31 \mathrm{D}$, in the intensity of $20 \mathrm{~cm}$, indicate the possibility of selecting promising materials for cultivation in the semi-arid region of Pernambuco, with desirable morphological and productive characteristics to forage plants.

\section{ACKNOWLEDGES}

To CNPq (Conselho Nacional de Desenvolvimento Científico e Tecnológico) for the financial support and grants.

\section{REFERENCES}

Rev. Caatinga, Mossoró, v. 29, n. 3, p. 742 - 752, jul. - set., 2016 
ADJEI, M. B.; PITMAN, W. D. Response of Desmanthus to clipping on a phosphatic clay minespoil. Tropical Grasslands, Brisbane, v. 27, n. 2, p. 94-99, 1993.

ALLEN, V. G. et al. An international terminology for grazing lands and grazing animals. Grass and Forage Science, Oxford, v. 66, n. 1, p. 2-28, 2011.

ARAÚJO, S. A. C; DEMINICIS, B. B.; CAMPOS, P. R. S. S. Melhoramento genético de plantas forrageiras tropicais no Brasil. Archivos de Zootecnia, Córdoba, v. 57, n. 1, p. 61-76, 2008.

BREWBAKER, J. L. Leguminous trees and shrubs for Southeast Asia and the South Pacific. In: BLAIR, G. J.; IVORY, D. A.; EVANS, T. R. (Eds.). Forages in Southeast Asian and South Pacific Agriculture. ACIAR Proceedings, Canberra, 1987, p. 43-50.

FONTENELE, A. C. F. et al. Leguminosas tropicais: Desmanthus virgatus (l.) Willd. uma forrageira promissora. Revista Brasileira de Agrociência, Pelotas, v. 15, n. 1-4, p. 121-123, 2009.

FREITAS, A. D. S. et al. Nodulação e fixação de nitrogênio por forrageiras da caatinga cultivadas em solos do semiárido paraibano. Revista Brasileira de Zootecnia, Viçosa, v. 40, n. 9, p. 1856-1861, 2011.

GONZALEZ-V., E. A.; HUSSEY, M. A.; ORTEGA -S, J. A. Nutritive value of Desmanthus associated with kleingrass during the establishment year. Rangeland Ecology and Management, Burns, v. 58, n. 3, p. 308-314, 2005.

JONES, R. M.; BRANDON, N. J. Persistence and productivity of eight accessions of Desmanthus Virgatus under a range of grazing pressures in subtropical Queensland. Tropical Grasslands, Brisbane, v. 32, n. 3, p. 145-152, 1998.

KARIM, A. B.; RHODES, E. R.; SAVILL, P. S. Effect of cutting height and cutting interval on dry matter yield of Leucaena leucocephala (Lam) De Wit. Agroforestry Systems, Dordrecht, v. 16, n. 2, p. 129-137, 1991.

LEITES， L. P.; ZUBIZARRETA-GERENDIAIN, A.; ROBINSON, A. Modeling mensurational relationships of plantation - growth loblolly pine (Pinus taeda L.) in Urugay. Forest Ecology and Management, Eveleigh, v. 289, n. 1, p. 455-462, 2012.

LITTELL, R. C. et al. Statistical analysis of repeated measures data using SAS procedures. Journal of Animal Science, Champaign, v. 76, n. 44, p. 12161231, 1998.
LUCKOW, M. Monograph of Desmanthus (Leguminosae-Mimosoideae). [Ann Arbor, Mich.]: American Society of Plant Taxonomists, 1993. 166 p.

MARCELINO, K. R. A. et al. Características morfogênicas e estruturais e produção de forragem do capim-marandu submetido a intensidades e frequências de desfolhação. Revista Brasileira de Zootecnia, Viçosa, v. 35, n. 6, p. 2243-2252, 2006.

MELO, R. O. et al. Susceptibilidade à compactação e correlação entre as propriedades físicas de um Neossolo sob vegetação de Caatinga. Revista Caatinga, Mossoró, v. 21, n. 5, p. 12-17, 2008.

MEURIOT, F. et al. Contribution of initial $\mathrm{C}$ and $\mathrm{N}$ reserves in Medicago sativa recovering from defoliation: impact of cutting height and residual leaf area. Functional Plant Biology, Hobart, v. 32, n. 4, p. 321-334, 2005.

NUTTO, L. Manejo do crescimento diamétrico de Araucaria angustifolia (Bert.) O. Ktze. baseado na árvore individual. Ciência Florestal, Santa Maria, v. 11, n. 2, p. 9-25, 2001.

PALUDO, A. et al. Feijão guandu em três diferentes alturas de corte na alimentação de ruminantes. Revista Eletrônica Nutrime, Viçosa, v. 9, n. 5, p. 1981-1994, 2012.

PENGELLY, B. C.; LIU, C. J. Genetic relationships and variation in the tropical mimosoid legume Desmanthus assessed by random amplified polymorphic DNA. Genetic Resources and Crop Evolution, Dordrecht, v. 48, n. 1, p. 91-99, 2001.

QUEIROZ, I. V. Avaliação de germoplasma de Desmanthus ocorrentes em municípios representativos da caprino-ovinocultura no semiárido de Pernambuco. 2012. 90 f. Dissertação (Mestrado em Zootecnia: Área de Concentração em Forragicultura) - Universidade Federal Rural de Pernambuco, Recife, 2012.

RICHARDS, L. A. Diagnosis and improvement of saline and alkali soils. U. S. Dep. Agric. Handbook 60 Washington,. U. S. Government Printing, Office, D. C., 1954. 160 p.

SAS Inst. Inc. SAS statistic user's guide. Release version 6. SAS Ins. Inc., Cary, NC. 1999.

SHEN, Y. et al. Effects of cutting height on shoot regrowth and forage yield of alfalfa (Medicago sativa L.) in a short-term cultivation system. Grassland Science, Miyazaki, v. 59, n. 2, p. 73-79, 2013. 
SILVA, V. J. et al. Características morfológicas e produtivas de leguminosas forrageiras tropicais submetidas a duas frequências de corte. Revista Brasileira de Zootecnia, Viçosa, v. 39, n. 1, p. 97 102, 2010.

TAIZ, L.; ZEIGER, E. Phytochrome In: TAIZ, L.; ZEIGER, E. 2.ed. Plant physiology. Massachusetts: Publishers Sunderland, 1998. v. 1, cap. 17, p. 483516.

TEIXEIRA, V. I. et al. Aspectos agronômicos e bromatológicos de leguminosas forrageiras no Nordeste Brasileiro. Archivos de Zootecnia, Córdoba, v. 59, n. 226, p. 245-254. 2010.

TRUJILLO, W. et al. Effects of height and frequency of cutting on yield, quality and persistence of Desmanthus virgatus. Tropical Grasslands, Brisbane, v. 30, n. 4, p. 367-373, 1996. 